\title{
International donations to the Ebola virus outbreak: too little, too late?
}

\author{
Karen Grépin examines the pledges made to the Ebola crisis, how much has actually reached \\ affected countries, and the lessons to be learnt
}

\section{Karen A Grépin assistant professor of global health policy}

New York University, New York, UK

The World Health Organization was first alerted to the current outbreak of Ebola virus disease on 23 March $2014,{ }^{1}$ but it was not until 8 August, after a meeting of the International Health Regulations Emergency Committee, that it declared a public health emergency of international concern. ${ }^{2}$ This official declaration set into motion an international response to contain the outbreak. The international response has been called both too small and too slow, and this may have contributed to the ongoing spread of the disease. ${ }^{3}$

In this article, I examine the level and speed of the international donations to tackle the Ebola epidemic and how they aligned with evolving estimates of funds required to bring the epidemic under control. Understanding what has and has not worked well in the early phases of this crisis can help us learn from it and prepare for future humanitarian and public health emergencies. My analysis considers only international donations captured in the UN Office for the Coordination of Humanitarian Affairs' (OCHA) financial tracking system (http://fts.unocha.org, box), which does not capture all resources that have been pledged to the outbreak

\section{Funding needed for Ebola}

Guinea's Ministry of Health notified WHO of a "rapidly evolving outbreak" of Ebola virus disease in the southeastern part of its country on 23 March 2014, with 49 reported cases, including 29 deaths. ${ }^{7}$ Within a week of the notification, WHO sent an initial donation of protective equipment and other medical supplies to Guinea. ${ }^{7}$

By early April, WHO had made an initial appeal for $\$ 4.8 \mathrm{~m}$ ( $£ 3 \mathrm{~m} ; € 4 \mathrm{~m}$ ) to the international donor community, which typically includes international governments, international agencies, non-governmental organisations, and private corporations. Donations exceeded this target, with the European Commission's Humanitarian Aid and Civil Protection department (ECHO), Italy, South Korea, the United States, Canada, Germany, Japan, the United Kingdom, the African Development Bank, and a handful of private companies pledging a total of $\$ 7 \mathrm{~m}^{8}$
On 1 August, WHO, along with the presidents of Liberia, Sierra Leone, and Guinea, announced the Ebola virus disease outbreak response plan and called on international donors to provide $\$ 71 \mathrm{~m}$ to support the control of the outbreak. ${ }^{8}$ As the epidemic continued to spread out of control, in late August WHO released the Ebola response roadmap, which provided guidance on how to "stop Ebola transmission in affected countries within 6-9 months and prevent international spread." It estimated that $\$ 490 \mathrm{~m}$ would be required to implement the roadmap. ${ }^{9}$ Less than a week later, Margaret Chan, the director general of WHO, and other UN leaders revised this estimate up to $\$ 600 \mathrm{~m} .{ }^{10}$

On 16 September 2014, roughly six months after the start of the epidemic, OCHA released a report which estimated that nearly $\$ 1$ bn in humanitarian assistance would be required, based on the assumption that up to 20000 people would have been infected with the virus by the end of 2014 and that it would take 6-9 months to end transmission. By mid-November, after the creation of the United National Mission for Ebola Emergency Response, the official request for funding was estimated at \$1.5bn.

Clearly, international leaders have found it challenging to estimate the financial requirements to tackle this rapidly spreading outbreak. Although we still do not know what the total funding requirements will be, there seems to be consensus that at least $\$ 1.5 \mathrm{bn}$ will be required during the early phase of the response. Long term needs, which will include recovery and rebuilding efforts, are likely to be much higher.

\section{Funding pledged and delivered for Ebola}

Like the international response, contributions to fight the epidemic were slow to take off. Figure $1 \Downarrow$ provides an overview of the total resources pledged and delivered to deal with the Ebola outbreak from August 2014 until 31 December 2014 according to OCHA's financial tracking system as well as the amount requested. Because there is uncertainty about the dates at which pledges are actually paid in the tracking system, the lower line represents an optimistic estimate of actual transfer 


\section{OCHA's financial tracking system}

Humanitarian assistance is defined as financial transfers to affected regions to "save lives, alleviate suffering, and maintain and protect human dignity during and in the aftermath of emergencies." The primary source of data on humanitarian assistance comes from the UN $\mathrm{OCHA}$ financial tracking system (FTS), an online database that provides real time estimates of humanitarian assistance during ongoing emergencies (http://fts.unocha.org). Donors are the primary source of data, through regular reports of their financial activities using standard reporting forms. Data are cross checked by FTS staff and updated daily.

Donor activities are classified into one of three categories:

Pledge-A "non-binding announcement of an intended contribution or allocation by the donor"

Commitment - "The creation of a contractual obligation regarding funding between the donor and appealing organization or recipient. It almost always takes the form of a signed contract"

Paid contribution - "Payment or transfer of funds or in-kind goods from the donor to the appealing or recipient organization"5

OCHA considers both commitments and paid contributions as "funded" programmes. The database tracks each donor activity based on the date the original pledge was made but provides more limited data on dates that they moved to commitments or paid contributions.

Although donors are not obliged to report to the FTS, most donor countries, UN agencies, and international non-governmental organisations do so, as do many foundations and corporations. In addition, the FTS conducts research to find additional contributions, in particular resources that are provided from private sources such as trusts, foundations, and corporations. FTS uses news media to identify reports of donations and then follows up to get more information.

There are some important discrepancies between reported pledges by some donors in the media and what is recorded in the FTS, probably because the types of some donations do not qualify as humanitarian assistance in the FTS, most notably loans. ${ }^{6}$

Funding activities are traced according to their first channel of delivery, such as UN agency, non-governmental organisation, or direct transfer to country. In general, most governments channel their resources through UN agencies. Private sources, on the other hand, favour

non-governmental organisations. UN agencies or other channels may redirect resources to other implementing partners, but it is difficult to trace such subsequent activities in the $\mathrm{FTS} .{ }^{4}$ The data here therefore refer only to the first channel of delivery.

of resources; the actual date of transfer may have followed the date of commitment.

As of 31 December 2014, donors had pledged a total of $\$ 2.89 \mathrm{bn}$ to support the international response to the Ebola outbreak; however, only $\$ 1.09 \mathrm{bn}$ has actually been paid. I estimate that it took until at least mid-October before the affected countries received $\$ 500 \mathrm{~m}$ and until at least December before they got $\$ 1$ bn. Since late September, international donors have pledged more to the Ebola response than has been officially requested by international leaders. Actual disbursement of funds, however, still lags behind the total amount requested.

The table $\Downarrow$ summarises the top donors to the Ebola outbreak. The United States ranks as the largest donor, with over $\$ 900 \mathrm{~m}$ in total pledges, followed by the United Kingdom (\$307m), the World Bank (\$230m), and Germany $(\$ 161 \mathrm{~m})$. The speed with which donors have converted their pledges into either paid contributions or firm commitments ("funded") varies. As of 31 December 2014, the United States had funded 95\% of its total pledges, whereas the World Bank had funded only about half. It is worth noting that the World Bank and other multilateral agencies have also extended loans to countries affected by Ebola, and this is not captured in the tracking system data because it is not generally considered humanitarian assistance.

Figure $2 \Downarrow$ shows where donations have gone. A little more than $40 \%$ of total pledges have been made to the region as a whole, which includes any country in west Africa, rather than to individual countries. Many donations are not country specific because non-governmental organisations have operations in more than one country. Liberia is the single biggest recipient of resources from donor countries, receiving over $\$ 882 \mathrm{~m}$. Countries other than the three with large Ebola outbreaks have also received funding from donors, mostly to finance preparedness activities, including Ivory Coast $(\$ 22 \mathrm{~m})$, Ghana $(\$ 14 \mathrm{~m})$, Mali $(\$ 11 \mathrm{~m})$, Nigeria $(\$ 4 \mathrm{~m})$, and Senegal $(\$ 3 \mathrm{~m})$. Twelve other African countries each received less than $\$ 2 \mathrm{~m}$.

On 31 December the WHO situation report reported that there had been 8018, 9446, and 2707 cases of Ebola in Liberia, Sierra Leone, and Guinea, respectively. Considering the country specific donations only, this translates into $\$ 110000$ per case in Liberia, \$49 000 in Sierra Leone, and \$86 000 in Guinea. Liberia has received roughly twice as much per case than Sierra Leone, although the data do not show how donations to non-governmental organisations have been allocated across the three countries.

Bilateral donors, such as the United States and United Kingdom governments, have contributed $60 \%$ of donations (fig $3 \Downarrow$ ). Private sources contributed a relatively large share-private individuals and organisations (10\%), foundations (8.3\%), and companies $(6.6 \%)$-whereas multilateral organisations, such as the World Bank, contributed only $11.5 \%$ of total donations. UN agencies, including WHO and Unicef, are leading recipients followed by non-governmental organisations. Only $11.5 \%$ of resources have gone directly to governments in affected countries. This suggests that much of the response has been led by international actors rather than national actors, which could have long term implications for the recovery from the outbreak. Several countries have sent medical teams to affected countries, but this type of donation is likely to be underestimated in the tracking system data because it is hard to value. Teams from China and Cuba have received substantial media attention. ${ }^{11}{ }^{12}$ The global health activities of these non-traditional donors are less well known, but China is an increasingly important donor in Africa. ${ }^{13}$ Private sources have also been major contributors to the outbreak - for example, Paul Allen, the cofounder of Microsoft, made substantial donations.

\section{Matching donations to need}

Although the amount pledged to support the international response to the Ebola outbreak exceeds the estimated total needs, the actual amount paid so far comprises only two thirds of these needs. Substantial donor support did not reach affected countries until October, more than six months after WHO was alerted to the outbreak. These delays in disbursements of funding may have contributed to spread of the virus and could have increased the financial needs. The problem has not been the generosity of donors but that the resources have not been deployed rapidly enough. The data do not allow the speed of response to be compared with that for other humanitarian crises, but they do suggest that we need a mechanism to enable more rapid disbursement of funds to fight public health threats such as Ebola-for example, as a dedicated fund that could be rapidly deployed for any emergency. Existing contracting mechanisms are too slow. International leaders have recently voted to overhaul how WHO deals with such crises, ${ }^{14}$ including the establishment of a $\$ 100 \mathrm{~m}$ dedicated fund, which is a welcome 
development but must also include reforms in the processes that lead to the recognition of such threats and to trigger the disbursements of these funds.

Donors face many competing demands for their limited foreign aid and humanitarian assistance budgets. The total commitment to all humanitarian emergencies in 2013 - for example, in Syria and South Sudan — was \$22bn, already an all time high. ${ }^{4}$ Given this, it is notable that donors' response to the epidemic has been relatively robust.

The resources available to tackle the Ebola crisis are likely to be greater than those identified here. The FTS captures only donations made by international donors. It neglects domestic resources and does not adequately capture donations given in kind or in the form of loans. There is also some uncertainty on the dates in the database. In addition, the system does not capture all resources devoted to combating Ebola, for example the Ebola emergency funding request made by the United States to its congress.

Monitoring and tracking donor responses to the epidemic, and how the money was spent, is important to improve our response to future public health threats. Although quantity of funding is important, so is the quality of the response. Directing funding through non-governmental organisations and UN agencies was probably key to ensure quick implementation. However, given that so few resources have been given to recipient governments, it is unclear what effect their activities might be having on health systems in affected countries and whether there are unintended consequences for other health system activities. ${ }^{15}$ Learning from this experience will help us to understand what worked and what did not in this epidemic and will also help us better assess funding needs in the future.

Contributors and sources: KG's research focuses on the economics and politics of health service delivery in sub-Saharan African health systems. Her research includes other studies on donor responses, such as to the HIV/AIDS epidemic, and the measurement of development assistance for health. KG conceived the research project and drafted the manuscript. Crossley Pinkstaff provided help with cleaning the data and generating figures.

Competing interests: I have read and understood BMJ policy on declaration of interests and have no relevant interests to declare.

Provenance and peer review: Not commissioned; externally peer reviewed.

1 WHO AFRO. Ebola virus disease in Guinea. 2014 www.afro.who.int/en/media-centre/ pressreleases/item/6391-ebola-in-guinea.html.

2 Briand S, Bertherat E, Cox P, Formenty P, Kieny M-P, Myhre JK, et al. The international Ebola emergency. N Engl J Med 2014;371:1180-3.

3 Strom S. Donations for Ebola relief are slow to gain speed. New York Times 2014 Oct 20. www.nytimes.com/2014/10/21/business/donations-for-ebola-relief-efforts-are-slowto-take-off.html? $r=0$.

4 Global Humanitarian Assistance Team. Global humanitarian assistance report 2014. www.globalhumanitarianassistance.org/wp-content/uploads/2014/09/GHA-Report-2014interactive.pdf.

5 UN OCHA. Definitions: pledge, commitment \& contribution. 2014. https://docs.unocha. org/sites/dms/CAP/FTS\%2002\%20Definitions\%20Pledge\%20Commitment\% 20Contribution.pdf.

6 Glassman A, Raghavan S. How much is actually being spent on Ebola? 27 Oct 2014. www.cgdev.org/blog/how-much-actually-being-spent-ebola.

7 WHO AFRO. WHO supplies arrive in Guinea to support the Ebola outbreak response. 2014. www.who.int/features/2014/guinea-ebola/en/.

8 WHO, Guinea, Liberia, Sierra Leone. Ebola virus disease outbreak response plan in west Africa. 2014. www.who.int/csr/disease/ebola/evd-outbreak-response-plan-west-africa2014.pdf?ua $=1$.

9 WHO announces $\$ 490$ million plan for fighting Ebola. PBS 2014 Aug 28. www.pbs.org/ newshour/bb/announces-490-million-plan-fighting-ebolas-spread/.

10 UN says $\$ 600$ million needed to tackle Ebola as deaths top 1900. Reuters 2014 Sep 3. www.reuters.com/article/2014/09/03/us-health-ebola-idUSKBN0GY1V320140903.

11 Birrell I. The Ebola outbreak has produced some real heroes-but Western governments are not among them. Independent 2014 Oct 19. www.independent.co.uk/voices/comment/ the-ebola-outbreak-has-produced-some-real-heroes--but-western-governments-are-notamong-them-9804894.html.

12 Cuba's impressive role on Ebola. New York Times 2014 Oct 20. www.nytimes.com/2014/ 10/20/opinion/cubas-impressive-role-on-ebola.html?_r=0.

13 Grépin KA, Fan VY, Shen GC, Chen L. China's role as a global health donor in Africa: what can we learn from studying underreported resource flows? Global Health 2014;10:84

4 Gulland A. WHO's crisis handling to be overhauled after slow response to Ebola. BMJ 2015;350:h460.

15 Grépin KA. HIV donor funding has both boosted and curbed the delivery of different non-HIV health services in sub-Saharan Africa. Health Aff (Milwood) 2012;31:1406-14.

Cite this as: BMJ 2015;350:h376

(c) BMJ Publishing Group Ltd 2015 


\section{Key messages}

Pledges to the Ebola outbreak have reached at least $\$ 2.89 \mathrm{bn}$

However, only about one third of these resources have been be disbursed to countries

Delays have occurred in requests for funding and translating pledges into paid contributions

New mechanisms to speed up disbursements could help in future crises

\section{Table}

Table 1 | Top 10 donors to tackle Ebola outbreak in 2014 as of 31 December

\begin{tabular}{|c|c|c|c|c|}
\hline Donor & Earliest pledge & Total pledged (\$m) & Total funded ${ }^{\star}(\$ m)$ & $\%$ Pledges funded \\
\hline United States & 31 July & 900 & 855 & 95 \\
\hline United Kingdom & 14 July & 307 & 302 & 98.4 \\
\hline World Bank & 8 September & 230 & 117 & 51.1 \\
\hline Germany & 9 May & 161 & 160 & 99.8 \\
\hline France & 15 April & 137 & 108 & 79.3 \\
\hline Paul G Allen & 1 August & 100 & 55 & 55.2 \\
\hline Sweden & 15 April & 78 & 77 & 99.4 \\
\hline Canada & 16 April & 78 & 78 & 100 \\
\hline $\mathrm{ECHO}$ & 20 August & 75 & 75 & 100 \\
\hline Netherlands & 28 August & 66 & 60 & 90.7 \\
\hline
\end{tabular}

$\mathrm{ECHO}=$ European Commission Humanitarian Aid and Civil Protection.

*Paid or firmly committed. 


\section{Figures}

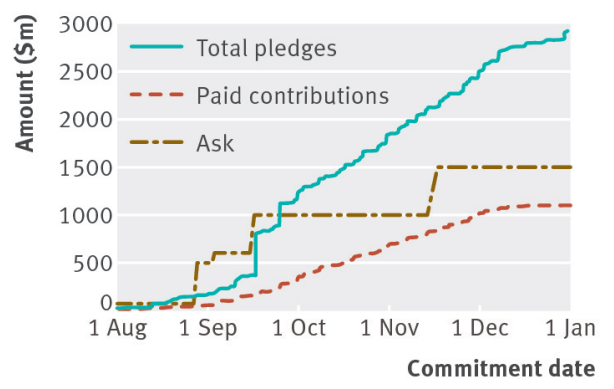

Fig 1 Total donor support to west African Ebola outbreak and the amount asked for by international organisations

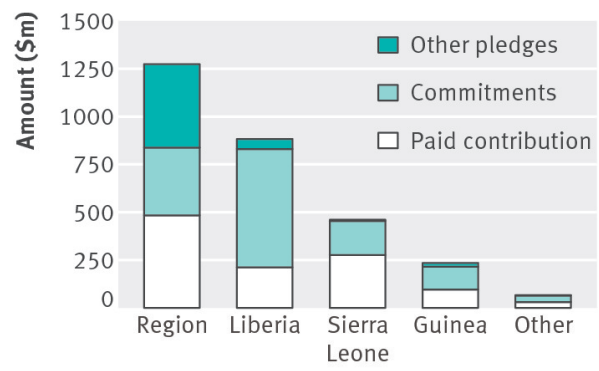

Fig 2 Distribution of donor support to Ebola outbreak in west Africa

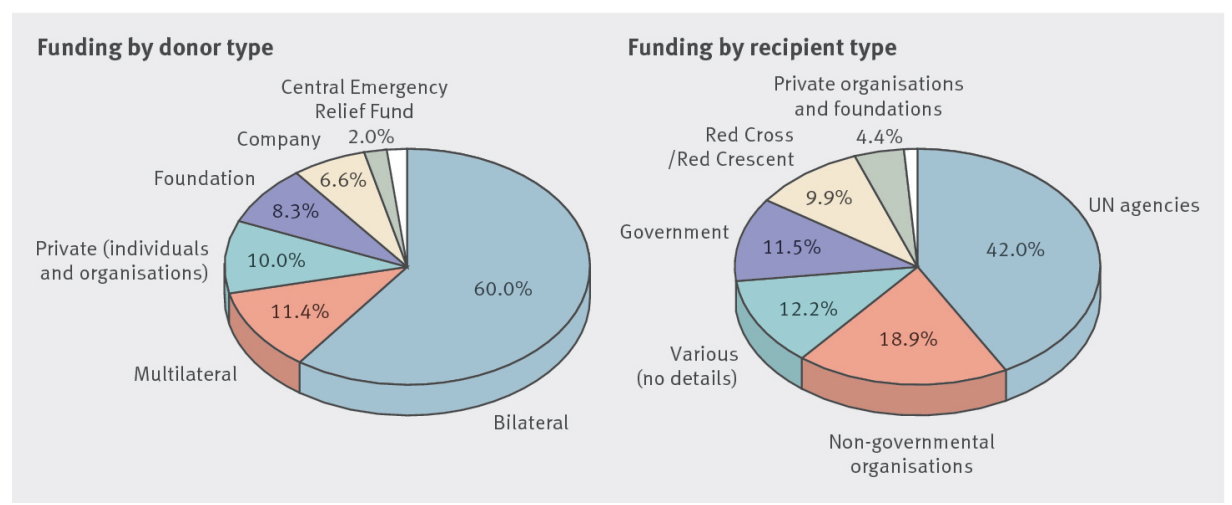

Fig 3 Types of donors and recipients of funding for Ebola outbreak 